総

\title{
バリヤー型陽極酸化皮膜の特性とその評価法
}

\author{
加 藤 正 義*
}

\section{The Characteristic and the Evaluation of the Barrier Type Anodic Oxide Film}

\author{
Masayoshi KATOH*
}

\begin{abstract}
Mainly with regard to the barrier films on $\mathrm{Al}$ and partly on $\mathrm{Ta}$, the influence of pretreatments, forming electrolyte, anodizing conditions and heating in air, water or electrolyte solutions on the leakage current, $\tan \delta$, durability for water and acid, transient behaviour and breakdown voltage were reviewed along with the characterization of the film.

In conclusion, it is emphasized that the characteristic of the film is not inherent but is so variable as to be markedly influenced by those factors listed above, especially by anion species in the forming electrolyte.

Key Words : Anodic Oxide Film, Barrier Film, Anodization of Aluminum
\end{abstract}

\section{1.は じめに}

1886年にチャールス・マルチンホールが溶融塩電解に よってアルミニウムの製造に成功して以来, 約 100 年が 経過した。また Al 電解コンデンサーの歴史はその約半 分の50年になる。そしてこの50年間に，このコンデンサ 一は長足の進歩を遂げ, $0.1-10000 \mu \mathrm{F}$ といら大容量範 囲をカバーする安価なコンデンサーとして広く使用され るに至った。今日わが国に拉ける生産は月間15億個に達 し, その年間伸び率は $17 \%$ と, 半導体集積回路の $24 \%$ に 匹敵する進展をみせている。しかしながら電解コンデン サーは半導体のような能動素子に比べて未だ基板専有面 積が大きいので更に一層の小型化が望まれている。

一方ポーラス型 $\mathrm{Al}$ 陽極酸化皮膜は従来の構造材料と しての用途の他に，多くの機能的な用途が期待されてい るが，この皮膜も下層はバリヤー皮膜であるから，その 特性は下層の影響を強く受けることになる。従ってこれ らの研究にも表題のような情報が必要になると思われる。 経験によれば, 皮膜の特性はケミカルな因子, 特に化 成液に大さく左右され, また皮膜は, 電場, 水との接触, 加熱等の外的因子に非常に敏感であり, あたかも環境と の間で呼吸をしているといら感じさえする。

本文では筆者の研究を中心に，これらの問題を紹介す る。主としてアルミニウムの話になるが, 一部タンタル

* 東京理科大学工学部 (†162 東京都新宿区神楽坂1-3)

Fac. of Eng., Science Univ. of Tokyo (1-3, Kagurazaka, Shinjuku-ku, Tokyo 162)
も含めたい。な特省紙面のために，以下次のような略号 を用いることにする。

略号: 漏えい電流 (LC), 容量 (Cap), 誘電正接 $(\tan \delta)$, 絶縁破壊電圧 $\left(V_{\mathrm{B}}\right)$, 化成電圧 $\left(V_{\mathrm{f}}\right)$, 作動電 圧 $\left(V_{\mathrm{w}}\right)$

\section{2. 化 成 法}

\section{1 化 成 液}

基本的には, 中性溶液でかつ $\mathrm{Al}$ を腐食し難い溶液が 用いられる。例えば, アジピン酸塩, ホウ酸塩, リン酸 塩, フタル酸塩, マレイン酸塩, 安息香酸塩及び酒石酸 塩やクエン酸塩のようなオキシ酸塩等が挙げられるが, 実用的には第 1 - 3 番目の塩が最も多く用いられている ようである。通常アンモニウム塩が多用されているが， アルカリ金属塩も用いられ，カチオン種によってもその 特性は大さく変わる。

表 1 に筆者の研究に用いた化成液とその略号を示した。 以下の本文では, この略号を用いる。

化成液は, 高純度塩を高純水に溶解して作られ, 重金 属塩や塩化物イオンは絶対に, またホコリ等の固形物の 混入も極力避けねばならない。

また化成の総括反応は, 次式のように表わされるから, $2 \mathrm{Al}+3 \mathrm{H}_{2} \mathrm{O} \rightarrow \mathrm{Al}_{2} \mathrm{O}_{3}+6 \mathrm{H}^{+}+6 \mathrm{e}$ 化成液に緩衝性がないと, 界面の $\mathrm{pH}$ がかなり低下して 皮膜の溶解が併発し，化成の電流效率が低下寸るととも に多くの場合 LC も増大する。従って同一の電解質でも 緩衝性を示す $\mathrm{pH}$ 領域の溶液を用いた方がよい)(ただ 
Table 1 Some examples of the forming electrolyte.

\begin{tabular}{l|c|c|c|c}
\hline \multicolumn{1}{c|}{ Electrolyte } & Abbreviation & $\begin{array}{c}\text { Concentration } \\
{[\mathrm{g} / \mathrm{L}]}\end{array}$ & $\mathrm{pH}$ & $\begin{array}{c}\text { Specific } \\
\text { Resistance } \\
{[\Omega \cdot \mathrm{cm}]}\end{array}$ \\
\hline $\begin{array}{l}\text { Ammonium Adipate } \\
\mathrm{NH}_{4} \mathrm{COO} \cdot\left(\mathrm{CH}_{2}\right)_{4} \cdot \mathrm{COONH} \mathrm{N}_{4}\end{array}$ & Ad & 150 & 6.8 & 7.8 \\
\hline \begin{tabular}{l}
$\mathrm{Ammonium} \mathrm{Borate}_{\mathrm{NH}_{4} \mathrm{BO}_{2}}$ \\
\hline $\begin{array}{l}\text { Ammonium Dihydrogen } \\
\text { Phosphate } \mathrm{NH}_{4} \mathrm{H}_{2} \mathrm{PO}\end{array}$
\end{tabular} & $\mathrm{P}$ & 100 & 6.0 & 8.0 \\
\hline $\begin{array}{l}\text { Potassium } \mathrm{Hydrogen}_{4} \\
\text { Phthalate } \\
\text { KOOC} \cdot \mathrm{C}_{6} \mathrm{H}_{4} \cdot \mathrm{COOH}\end{array}$ & $\mathrm{Ph}$ & 20 & 5.0 & 55 \\
\hline
\end{tabular}

し他の特性を損なわない限り)。

\section{2 化 成 法}

\section{2 .1 試料之前処理}

純度は特性，特に LC に大きく影響するので，なるべ く $99.99 \%$ 程度の高純度試料を用いる。焼鈍の有無とそ の条件とはエッチングには大きく影響するが，他の特性 に及ぼす影響についてはあまり明らかでない。

エッチングはコンデンサーの小型化涼めて重要で, 高度の技術を必要とするが，本文では極く簡単に後述す るに留める。

前処理は, メタノールやアセトンによる脱脂に続いて 通常次の何れか, または併用の処理が行われる。

(1) 高濃度, 高温 $\mathrm{NaOH}$ 処理, 処理例; $10 \mathrm{~N} . \mathrm{NaOH}$, $50^{\circ} \mathrm{C}, 30 \mathrm{~s}$ ，(2) 上記に続く軽い直流電解エッチング処 理; 処理例 $24 \mathrm{wt} \% \mathrm{NaCl}$ 中, $85^{\circ} \mathrm{C}, 300 \mathrm{~mA} / \mathrm{cm}^{2}, 5 \mathrm{~min}$, (3)化学研磨; $\mathrm{HNO}_{3}$ と $\mathrm{H}_{3} \mathrm{PO}_{4}$ の $1: 6$ 混合溶液中に 85 ${ }^{\circ} \mathrm{C}$ で，3-5 min.浸せき，(4)リン酸ーク口ム酸混液処理, 処理例 ; $2 \% \mathrm{CrO}_{3}+5 \% \mathrm{H}_{3} \mathrm{PO}_{4}, 60{ }^{\circ} \mathrm{C}$ 。(5)電解研磨, 処理例; 水酢と $\mathrm{HClO}_{4}(70 \%)$ の $: 1$ 混合溶液中, $15^{\circ} \mathrm{C}$, $100 \mathrm{~mA} / \mathrm{cm}^{2}$

上記の処理後適当な後処理一充分な水洗を経て直ちに 化成に入る。短時間でも水中または大気中に放置すると 表面皮膜が生長するので好ましくない2 2 。試料の液面部 には樹脂コートをする。コートしないと液のはい上がり により LC が異常に大きくなる。

(1)，(2)は筆者の処理法で, 軽いェッチングが皮膜に 対するアンカー効果をもつので特性のバラッキが少なく なるが, 表面積が不明になるので定量的な解析には不向 きである。この点では, ラフネスファクターが 1 に近い (3)の電解研磨が好適であるが，一方この処理によって 生成した皮膜内には微量の $\mathrm{Cl}^{-}$が混在するので, 化成時 に久陷の存在を示寸パルス状ノイズが発生するといわれ ている ${ }^{3)}$ 。前処理によって生成する表面皮膜の影響につ いては高橋, 永山らの研究 ${ }^{3)}$ が有益である。

恒温, 定電流密度 $\left(1 \mathrm{~mA} / \mathrm{cm}^{2}\right.$ 程度) でゆっくりとか きまぜながら化成すると, 電圧*は図 1 のように直線的

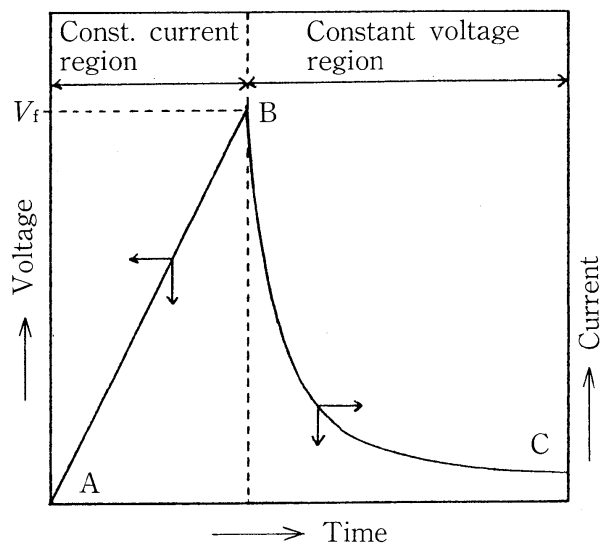

Fig. 1 Schematic illustration of the anodizing process.

Table 2 Current efficiency in the anodization of $\mathrm{Al}^{1}$.

B 4 ; (Boric acid + Ammonia) solution whose $\mathrm{pH}$ was adjusted to 4.0

B 6 ; Ibid. except that $\mathrm{pH}=6.0$

\begin{tabular}{c|c|c|c|c}
\hline Anodizing solution & Ad & P & B4 & B6 \\
\hline $\begin{array}{c}\text { Curreńt efficiency } \\
(\%)\end{array}$ & 99.4 & 74.3 & 80.2 & 90.9 \\
\hline
\end{tabular}

に上昇する。しかし皮膜溶解性の液, 例觉ば比較的濃厚 なリン酸塩溶液の場合には上に凸の曲線となり, 電流効 率は低い。電流効率の一例を表 2 に示した1)。

所望の電圧に達したら, その電圧に保持すると, 皮膜 の不完全部分が修復されて電流は図 1 の線 $\mathrm{BC}$ のように 減少するので, ほぼ定常状態になったら適当な所で終了 する。この時間が長すぎると皮膜は徐々に多孔質化して LC が上昇し始めるので好ましくな(、) 6)。試料を引き 上げ，よく水洗して完了する。しかし場合により皮膜の 改質を目的として，化成の前後にいろいろな溶液中への 浸せきとか, 熱処理, 再化成等がなされる（後述）。

* 液抵抗が大きい場合は参照電極を用いた方がよいが，この場 合は $\mathrm{C1}^{-}$が混入しないように注意する。 


\section{3. 皮膜特性と評価法}

\section{1 漏えい電流 $(\mathbf{L C})$}

\subsubsection{LC について}

理想的なコンデンサーは直流を通さないが，現実には 僅かな LC が流れる。LC は素子を発熱させ, 電圧と電 流の位相差を90度より減ずるので，好ましくない。つま りバリヤー本来の特性が失われることになる。

コンデンサーの LC といえば，通常ペーストを介して の最終製品に作動電圧（通常化成電圧の65-70\%）をか けた時の電流を指すが，化成後の LC といえば通常図 1 のC点付近，つまり化成電圧をかけた時の定常值を指す。 しかし当然のことながら LC は電圧に依存する。その挙 動をモデル的に示すと図2 のようになる。図の $\mathrm{AB}$ 領 域では電子電流 $\left(I_{\mathrm{e}}\right)$ が支配的で, オーム則が成立し, $\mathrm{D}$ より右方の領域ではイオン電流 $\left(I_{\mathrm{ion}}\right)$ が支配的で

$$
\begin{aligned}
& I_{\text {ion }}=\mathrm{A} \cdot \exp \left(b^{\prime} V / d\right) \quad(d \text { は皮膜の厚さ }), \text { または } \\
& V=a+b \cdot \log I
\end{aligned}
$$

の関係が成立する。 $\mathrm{BD}$ 間では混合導電となるが， $\mathrm{E}$ 点 付近にある $V_{\mathrm{f}}$ ではイオン導電が支配的となる。また $\mathrm{C}$ 点付近にある $V_{\mathrm{w}}$ では混合導電となり,

$\mathrm{LC}=I_{\mathrm{e}}+I_{\text {ion }}$ が成立する。

\section{1 .2 電子電流と $\tan \delta$}

$I_{\mathrm{e}}$ は皮膜の半導体的特性に依存し，その機構はかなり 複雑であるが，大まかに言えば皮膜の金属側ではカチオ ン過鄱で $n$ 型, 溶液側ではアニオン過㮃で $p$ 型となり, この $n-i-p$ 接合のゆえに $I_{\mathrm{e}}$ は，金属 $\rightarrow$ 溶液側に流れ難 く，反対方向に流れ易い?。バルブ金属と言われるゆえ んである。

$\tan \delta$ は通常数ボルト以下で測定されるので, この值 は電子電流抵抗の物指しになる。これに対して LC の場

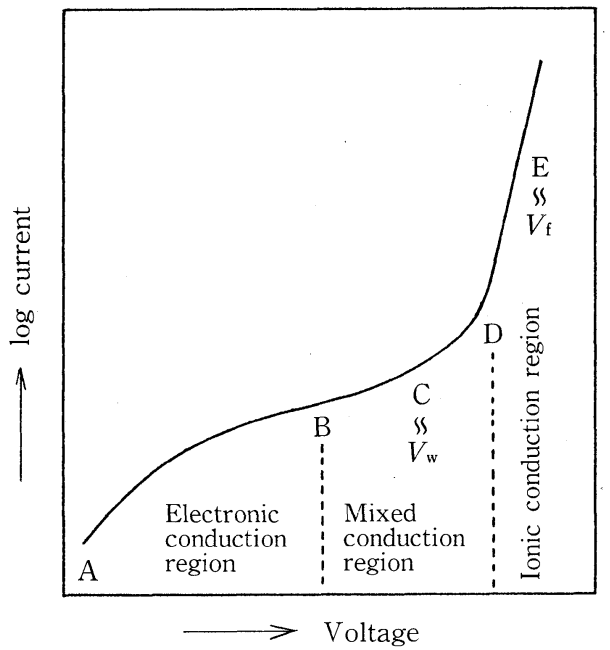

Fig. 2 Schematic illustration of $V$-log $i$ relationship of the film after anodization.

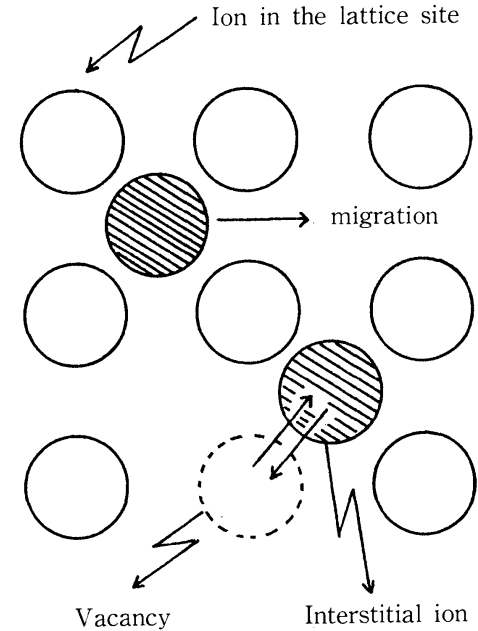

Fig. 3 Schematic illustration of the Frenkel Defect Model for migration of ions in the film.

合はイオン電流が支配的な領域における測定値であるか ら両者の順位は必ずしも一致しない。

3.1 .3 イオン電流と熱処理

イオンの泳動については, Vermilyea ${ }^{8)}$, Dewald ${ }^{9)}$, Young ${ }^{10)}$ らによるフレンケル欠陷説が有力で, これを モデル的に示すと図3のようになる（簡単化のため対イ オンは除いた)。

即ち泳動するカチオンまたはアニオンは, 格子点から 励起されて生じる介在位置にあるものだけであり, イオ ンはあとに残った空孔と，介在位置との間で平衡状態に ある。泳動電流はよく知られた次式

\section{$i=2$ anע.exp $\{(-W+q a E) / k T\}$}

で表わされる。この式より, 電流は介在イオン濃度 $n$ に比例するが， $n$ は電場がかかるとそのエネルギーで格 子点のイオンが励起されてくるので増加する。電場を切 ると再び徐々に空孔に落ちこむが，その速度は常温では 極めて技そく，高温になるほど早くなる。それゆえ化成 皮膜を熱処理後に再び電場を印加した時には特異な過渡 現象が現れる。

図 $4^{11)}$ は希リン酸溶液中 $240 \mathrm{~V}$ で化成した焼結 $\mathrm{Ta}$ 試 料 $(1000 \mu \mathrm{FV})$ を熱処理後再び同一溶液中に浸せきし, $300 \mu \mathrm{A}$ の定電流を流した時の電圧の経時変化を示した ものである。高温熱処理程空孔への落ちこみ速度が大き いので $n$ が小，従って抵抗が大きくなるので初期の電 圧は高くなっている。しかし電場の印加によって再び $n$ が増加し始めるので, 抵抗が減り, 電圧は減少して定常 状態に達する。 $\mathrm{Al}$ の場合も全く同様の挙動を示す。

図 5 は同上の化成試料を熱処理後今度は定電圧 (化成

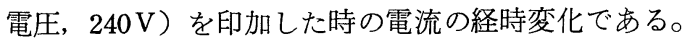
熱処理により $n$ が減少するので, 初期に過大な充電電 流が流れた後の電流は極めて小さい。しかしこの場合も 


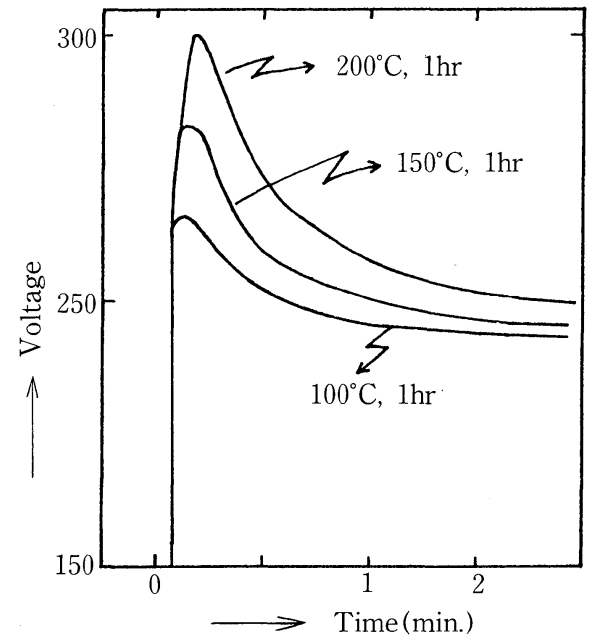

Fig. 4 Transient curves at a constant current $(300 \mu \mathrm{A})$ in dil. $\mathrm{H}_{3} \mathrm{PO}_{4}$ after heating the anodized sintered $\mathrm{Ta}$ pellets.
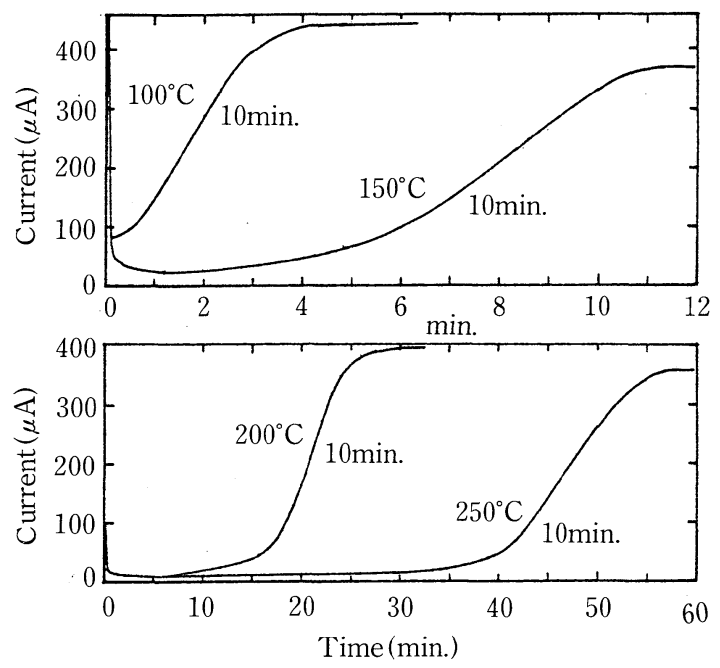

Fig. 5 Transient curves at a constant voltage $(240 \mathrm{~V})$ in dil. $\mathrm{H}_{3} \mathrm{PO}_{4}$ after heating the anodized sintered $\mathrm{Ta}$ pellets.

電場と電流とによる $n$ の増加によって電流は徐々に増 加してゆき, 定常状態（励起速度＝落ち込み速度）に達 する。そしてこの定常電流值は化成終了時の值（図 1 の C 点) にほぼ等しい。

加藤 ${ }^{12), 13)}$ は Dewald 式 ${ }^{9)}$ を修正し, その式より理論 過渡現象曲線を誘導した。その結果, 低温熱処理では実 測曲線とよく一致したが, 高温になるに従って偏差が大 きくなることを認め，これは熱による皮膜の劣化による ものであることを明らかにした。また実測過渡現象式と 照合することによって, 皮膜の熱劣化度を評価すること ができ, その結果熱処理条件が苛酷（高温, 長時間）に なるほど劣化の度合いが大きくなることを明らかにし

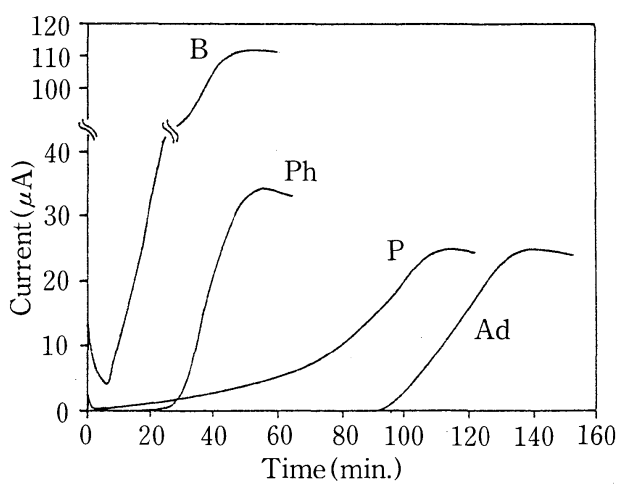

Fig. 6 Transient curves at a constant voltage $(70 \mathrm{~V})$ in various solutions after heating the anodized $\mathrm{Al}$ in the same solutions $\left(V_{\mathrm{f}}=70 \mathrm{~V}\right)$.

The heating condition; $250^{\circ} \mathrm{C}, 10 \mathrm{~min}$.

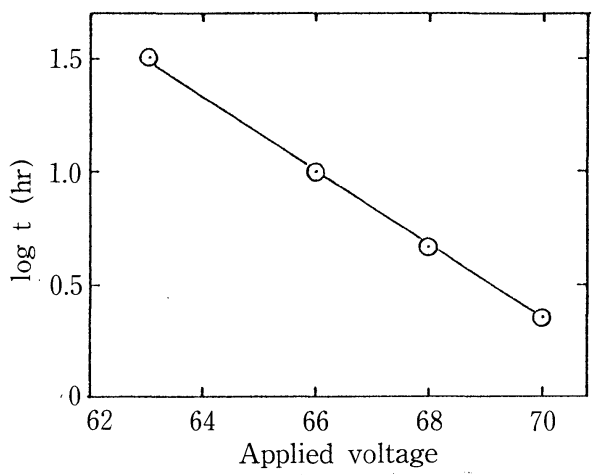

Fig. 7 The logarithm of time for reaching the steady state current during the transient when a constant voltage was applied to an anodized $\mathrm{Al}\left(V_{\mathrm{f}}=70 \mathrm{~V}\right)$ in adipate solution.

$た^{14)}$ 。

以上はTa の場合であったが，図 6 は Al の場合で, $70 \mathrm{~V}$ 化成後 $250^{\circ} \mathrm{C}$ で10分間熱処理した後再び同一化成液 中に浸せきして $V_{\mathrm{f}}$ を印加した時の過渡曲線である。図 より化成液の種類によって立ら上がり曲線が著しく異な ることが知られる15)。

図 7 は前図の Ad 液について, 熱処理後の印加電圧と 立ち上がり時間 $t$ の対数との関係をプロットしたもので あるが，両者の関係は $\log t=a-b V$ といら実験式で表 わされた ${ }^{15)}$ 。それゆえ仮に $70 \mathrm{~V}$ 化成のコンデンサーに対 する作動電圧を $50 \mathrm{~V}$ とすると，50V印加時に電流の立ち 上がるまでの時間は約 100 日と，極めて長くなる。熱処 理条件を $250^{\circ} \mathrm{C}, 10$ 分よりも更に高温, 長時間にすると, $t$ は数年-数十年というような值になると推算される。

乾式電解コンデンサー（ペースト型）の， $V_{\mathrm{w}} / V_{\mathrm{f}}$ は $70 \%$ 前後であるから，熱処理を充分に行らことによって 耐用期間内では立ち上がらず，低 LC を保持させること が可能になる。この観点から図 7 を眺めると, 立ち上が り時間の長くなる $\mathrm{B}<\mathrm{Ph}<\mathrm{P}<\mathrm{Ad}$ の順に $\mathrm{LC}$ 特性は良 


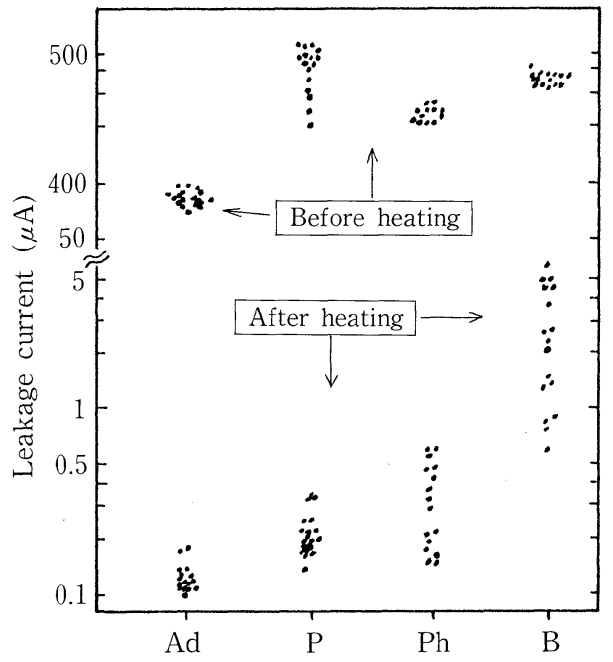

Fig. 8 Effect of the heating $\left(250^{\circ} \mathrm{C}, 10 \mathrm{~min}\right.$. $)$ on the leakage current in the anodization of $\mathrm{Al}\left(V_{\mathrm{f}}=70 \mathrm{~V}\right)$.

いとい方る。

図 8 は化成直後（加熱前, 図 1 のC点）の LC と, $250^{\circ} \mathrm{C}, 10$ 分加熱後同一化成液中に浸せきして $V_{\mathrm{f}}$ を印 加した時の 5 分後の LC とを示したものである。LC 低 下に及ぼす熱処理の効果は顕著であり, 特に Ad 液が優 れ， B 液が最も劣ることが知られた。

しかし一方, 熱処理は皮膜にクラックやボイドを生じ, 結晶化を促進するという点に拈いては好ましくない。従 って熱処理後に再化成その他の皮膜修復処理を行わねば ならないが，再化成電圧が高すぎたり，時間が長すぎた りすると前述のようにLC が再び増加してくるので，好 ましくない。これらの諸条件を加味した最適条件を見い 出すことが，皮膜特性向上のための重要なポイントとな る。

\section{2 耐水和性と耐酸性}

\section{2 .1 耐水和性}

$\mathrm{Al}$ のバリヤー皮膜はTa のそれに比べて水和し易く, 高温水では急速に, また常温水でも長時間のらちには水 和し, オキソ橋 $(-\mathrm{Al}-\mathrm{O}-\mathrm{Al}-)$ が各所で分断されて, $\mathrm{Al}-\mathrm{OH}$ のような非架橋酸素部分が増し, これが耐圧の 低下と LC 増加の主因になる。

最近金野, 永山ら ${ }^{16)}$ は, XPS による皮膜内水酸イオ ン濃度の分布を測定した結果, ホウ酸塩溶液中で化成し た皮膜を水中に浸せきした時の耐圧低下は，皮膜の溶解 によるものではなく, 水和によって皮膜外層の $\mathrm{OH}$ 濃 度が増し，それによるインピーダンスの低下が原因であ ることを明らかにした。

図 9 は, 化成-熱処理-再化成後の試料（図 8 之同条 件）及びこの試料を沸騰水中に30分間浸せき（加速水和 劣化試験）した試片を各化成液中に再浸せきし，15 $\mu \mathrm{A}$

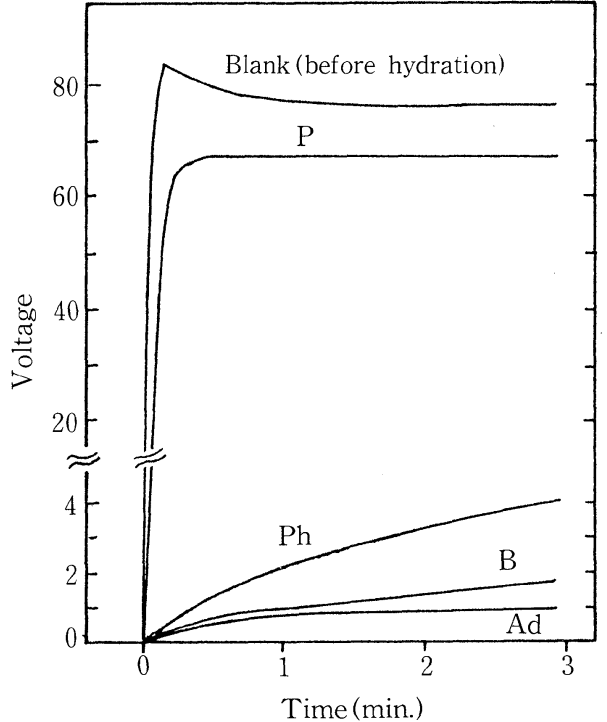

Fig. 9 Voltage build -up curves at a constant current $(30 \mu \mathrm{A})$ after immersion of the anodized $\mathrm{Al}$ in boiling water for $30 \mathrm{~min}$.

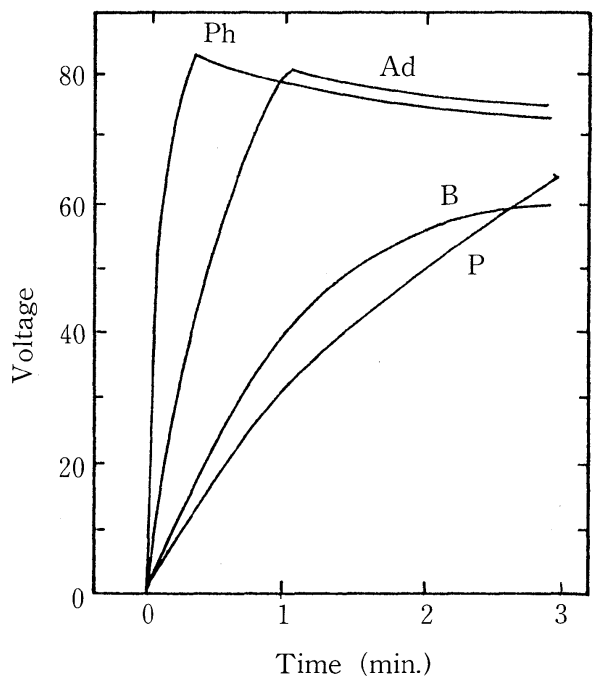

Fig.10 Voltage build -up curves at a constant current $(30 \mu \mathrm{A})$ after immersion of the anodized $\mathrm{Al}$ in $0.5 \mathrm{~N}$. $\mathrm{HNO}_{3}$ at $25^{\circ} \mathrm{C}$ for $30 \mathrm{~min}$.

$/ \mathrm{cm}^{2}$ の微少定電流を印加した時の電圧の立ち上がりを 測定したものである ${ }^{15)}$ 。劣化前の皮膜は化成液の種類に 依存せず，すべて図示のような電圧の急速な立ち上がり を示したが，沸騰水に浸せさ後の皮膜は著しく劣化し， 臣とど電圧の立ち上がりはみられなかった。しかし $\mathrm{P}$ 液だけは例外で，ブランクに比べて立ち上がり速度と到 達電圧とはやや小さくなるとはいえ, その劣化度は僅少 であった。また $\mathrm{P}$ 液以外の液では水和劣化後の容量及び $\tan \delta$ は，それぞれ劣化前の11-12倍および19-24倍にも 増加したが, $\mathrm{P}$ 液では, 両値共全く変化しなかった。

水中に $\mathrm{CrO}_{4}{ }^{2-}$ が存在する場合にも皮膜の耐水和性の 


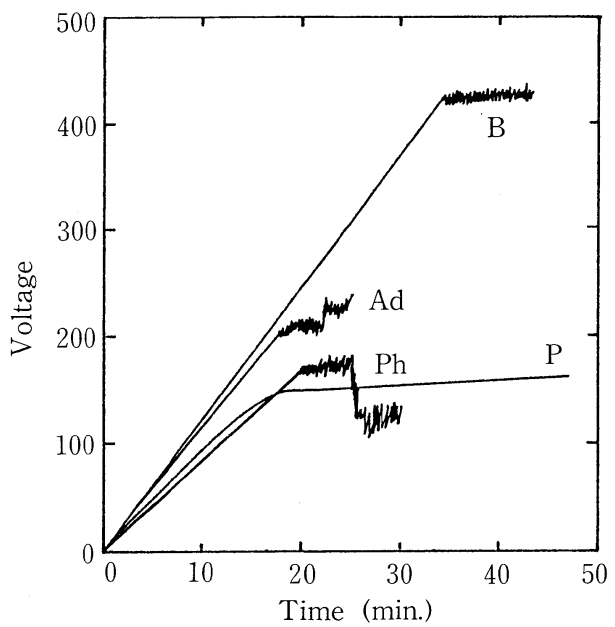

Fig.11 Variation of voltage with time during the anodization of $\mathrm{Al}$ at a constant current $(30 \mu \mathrm{A})$.

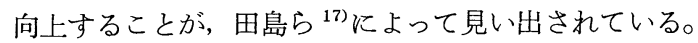
永山ら ${ }^{16)}$ は, ホウ酸塩溶液中で化成した皮膜を蒸留水中 及び0.001Mの $\mathrm{CrO}_{4}{ }^{2-}$ 溶液中に浸せきしたところ, 耐 水和性が著しく向上することを認め，XPS による結果 から皮膜の最外層に汪とんど単分子層で吸着している $\mathrm{CrO}_{4}{ }^{2-}$ が皮膜中への水分子の侵入を阻止して耐水和性 を向上させることを認めた。リン酸塩についても同様で ある。

\section{2 .2 耐酸性}

図 10は沸騰水の代わりに, $25^{\circ} \mathrm{C}, 0.5 \mathrm{~N} . \mathrm{HNO}_{3}$ 中に 30 分間浸せき後 $30 \mu \mathrm{A}$ の定電流を印加した時の電圧の立 ち上がり曲線を示したものである。劣化の程度は $\mathrm{Ph}$ $<\mathrm{Ad}<\mathrm{B}<\mathrm{P}$ 液の順に大となり, 耐水和性と耐酸性と には相関性はなく, 耐水和性の大きい $\mathrm{P}$ 液の耐酸性が最 も悪かった。

\section{3 絶緑破壊電圧}

図11に 4 種の溶液中で定電流化成した時の電圧の経時 変化を示した。いずれもある電圧（絶縁破壊電圧， $V_{\mathrm{B}}$ ) に達すると, 電圧の振動が始すり, 上昇が停止する。 $V_{\mathrm{B}}$ に達すると皮膜の各所で火花が発生し, 元々は非晶
質透明であった皮膜が徐々に結晶化して不透明になって いく。高圧用コンデンサーでは $V_{\mathrm{B}}$ の高いことが必須条 件であり，また $V_{\mathrm{B}}$ は不働態皮膜を作り易い $\mathrm{Al}, \mathrm{Ti}$ ， ス テンレス等の孔食電位とも関係しているので, その機構 の解明は重要である。

既往の研究によると, 絶縁破壊電圧に,

影響を及ぼさない因子；試片の形状，表面の荒さ， 化成条件（電流密度, 温度, かきまぜ条件等) 影響を及ぼす因子；

電解質の種類と濃度比抵抗依存説 濃度依存説

とが知られている。この後者の因子として，「種類と濃 度によって液の比抵抗が変わるから $V_{\mathrm{B}}$ が変わるのだ」 とする比抵抗依存説 ${ }^{18)}$ 20) と, 「種類と濃度それ自体が $V_{\mathrm{B}}$ を変える本質的な因子である」とする説 ${ }^{21)}$ 24) とが ある。

比抵抗依存説では, $V_{\mathrm{B}}=a+b \cdot \log R_{\mathrm{S}}$ という関係があるとしているが，加藤 ${ }^{23)}$ はこの説は誤 りで, 濃度依存説が正しく, 特にアニオン濃度に依存す る

$$
V=a-b \cdot \log \text { [anion] }
$$

といら実験式の成立することを明らかにした。この式は また佐藤 ${ }^{24)}$ の導いた理論式とも一致する。

しかしながら「なぜ $V_{\mathrm{B}}$ がアニオン種及びアニオン濃 度に依存するのか？」といら理由がまだ分からない。そ こで絶縁破壊に関する既往の説を紹介しながらこの問題 を考穴てみたい。表了は絶縁破壊に至る過程をモデル的 に示したものである。

絶縁破壊の主因が電子なだれにあることは多くの説で も一致しているが，そ机を誘発する一次因子が表中のど の過程になるかが各説によって違いがある。

古く, Seiz ${ }^{25)}$ は「一個の電子がカソードを出発して から約40回の衝突電離を繰り返せば固体は融解して絶縁 破壊を起こす」とした。電子の原子への衝突によって新 しい電子が放出され，所得倍増論的に電子の数は増すが, 一方衝突によって電子は運動のエネルギーを失う。両者

Table 3 Course of the break-down.

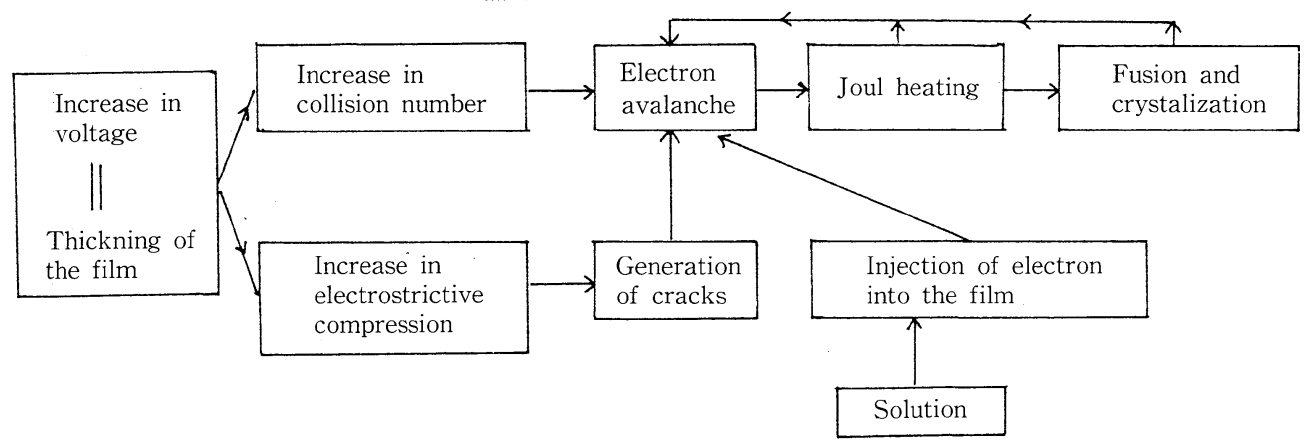


Table 4 Comparison among the barrier films formed in the several anodizing solutions.

\begin{tabular}{c|c|c|c|c|c}
\hline \multirow{2}{*}{} & \multirow{2}{*}{$\begin{array}{c}\text { Break-down } \\
\text { voltage }\end{array}$} & \multirow{2}{*}{ LC } & \multicolumn{2}{|c|}{ Durability } & \multirow{2}{*}{$\begin{array}{c}\text { Transient } \\
\text { behavior }\end{array}$} \\
\cline { 4 - 5 } $\mathrm{B}$ & $\begin{array}{c}(0 \\
1000 \mathrm{~V}\end{array}$ & $\times$ & $\times$ & $\times$ & $\times$ \\
\hline $\mathrm{Ph}$ & $\begin{array}{c}\triangle \\
200 \mathrm{~V}\end{array}$ & $\bigcirc$ & $\times$ & $\bigcirc$ & $\triangle$ \\
\hline $\mathrm{P}$ & $\begin{array}{c}\times \\
120 \mathrm{~V}\end{array}$ & $\bigcirc$ & $\bigcirc$ & $\times$ & $\bigcirc$ \\
\hline $\mathrm{Ad}$ & $\begin{array}{c}\triangle \\
250 \mathrm{~V}\end{array}$ & $\bigcirc$ & $\times$ & $\bigcirc$ & $\bigcirc$ \\
\hline
\end{tabular}

のバランスを考慮して立てた彼の式によれば，電子の数 $n$ は皮膜の厚さに比例し， $n$ がある限界值を超えると破 壊が起こることになる。それゆえ化成が進行して皮膜が ある厚さ(従ってある電圧)に達すると破壊が起こるとい ら現象をよく説明することができる。しかしながら彼の 説だけでは $V_{\mathrm{B}}$ が電解質の種類と濃度に大きく依存する という事実は説明できない。

一方表 3 で電䧺応力といらのは, 誘電体に強い電場が かかった時, 皮膜の両側に対置する異符号電荷によるク 一ロンカによって皮膜に強い圧縮応力がかかる現象をい う。そしてこの応力によって皮膜にクラックやスリップ を生じ，その部分に電子電流が集中して電子なだれを起 こす。破壊が起こるとスパークが生じてその部分は高温 になり, 結晶化して体積変化が起こり, これにより二次 的なクラックも生じて益々破壊が促進される。

最近, Wüthrich ${ }^{26)}$ は, 円盤電極法 ${ }^{27)}$,28) を用いてホ ウ酸アンモニウム溶液中で化成した $\mathrm{Al}$ 陽極酸化皮膜の 応力を測定した。それによると, 開路状態では引張り応 力であったものが,閉路状態(化成中)で,かつ $V<0.85$ $V_{\mathrm{f}}(V$ は印加電圧) の場合には,

$$
\sigma=27\left(V / V_{\mathrm{f}}\right)^{2} \quad \mathrm{~N} / \mathrm{mm}^{2}
$$

で示される圧縮応力に変わり, クーロン力だけによって 生ずる理論的な電歪応力式 $\sigma=\varepsilon E^{2} / 8 \pi(E$ は電場強度, $V / d)$ と, $V$ の二乗に比例するといら点でよく一致した。 しかし， $V>0.85 V_{\mathrm{f}}$ になると(つまりイオン電流支配領

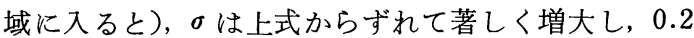
$\mathrm{mA} / \mathrm{cm}^{2}$ では $60 \mathrm{~N} / \mathrm{mm}^{2}, 1 \mathrm{~mA} / \mathrm{cm}^{2}$ では実に $320 \mathrm{~N} /$ $\mathrm{mm}^{2}$ にも達するとしている。1 $\mathrm{atm}=0.1 \mathrm{~N} / \mathrm{mm}^{2}$ である ことを考学ると，いかに大きな圧力が皮膜にかかるかが 分かる。彼はこの増加は, 皮膜内イオン泳動による欠陥 の増大とジュール熱による皮膜膨張とによると推論して いるが，詳細は不明である。

電歪応力説に基づくアニオンの影響としては, 二つの 因子が考学られる。その一つは，化成液中のアニオンが 皮膜内に侵入して皮膜の機械的強度を低下させるという 考方方 ${ }^{29}$ であり，他の一つは佐藤 ${ }^{24)}$ によるもので，皮 膜一溶液界面にアニオンが吸着して電歪応力が増大寸る
ために破壊が起こるという説である。共に興味ある説で はあるが，未だ確証がない。何れにしても，図11に示し たように， $V_{\mathrm{B}}$ は化成液中のアニオン種に大きく依存す る。

次に表 3 の「皮膜への電子注入」過程も重要であって, これが律速になると電子なだれを誘発する。地金金属／ 皮膜／対極といらコンデンサーは, 耐圧が低くて使いも のにならないことは良く知られている。これは電昰応力 等で皮膜に欠陥が生じた時に修復に要する酸素がないた めである。固体電解コンデンサーでは皮膜に $\mathrm{MnO}_{2}$ が 接しているので, この酸素が修復に役立つのである。し かしその供給速度は水溶液からのそれよりも遅いので耐 圧は水溶液の場合よりも低下する ${ }^{30,, 31)}$ 。

また経験によれば, 高濃度, 低温の化成液では化成中 に電解質が皮膜表面に析出し，これが絶縁破壊または電 圧上昇の停滞を生ずる。後者の場合は化成を一時中断し たり，温度を上げると再び電圧は上昇を続ける。

従って溶液側から皮膜への電子注入能も $V_{\mathrm{B}}$ や皮膜特 性に大きく影響するといえる。

\section{4 皮膜特性亡化成液}

表 4 に皮膜特性と化成液の種類との関係を定性的に示 した。すべての特性において優れた化成液といらものは なく，各液にはそれぞれ特徴があり，耐圧についてはB 液が，耐水和性についてはP夜が，過渡特性と漏えい電 流については Ad 液が優れているといえる。筆者の経験 では，容量は化成液の種類に依存しないが，Ad 皮膜の 方が P皮膜よりも大きいといら人もある。

これらの理由については明らかではないが，アニオン が皮膜内に混入するといら事実 ${ }^{16), 32), 33)}$ から考元ると， その影響がかなり大きいことは確かであろう。またこの ように皮膜の特性が化成液の種類に大きく依存するとい ら事実を我々はもっと注目すべきであろら。電解質の種 類や組み合わせは星の数ほどにもあるから今後の研究い かんによっては現用の化成液よりも飛躍的に優れたもの を見い出すことができるであろう。

\section{5 前, 中および後処理について}

以下紙面の都合で極く簡単に記す。 


\section{5 .1 電解エッチング}

大まかな傾向として，低圧用には AC，高圧用には

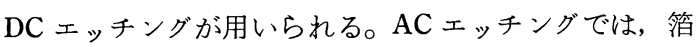
の両側に置いた対極間に交流を印加し，䇴自体に通電す る必要がないので大電流が流せ, 整流しないのでエネル ギーロスが小さく，また均一エッチングができるので機 械的強度が大きい等の利点がある。こういら静電誘導に よって溶解させる方式はコンデンサー業界では周知であ るが，他の業界では意外に知られていない。他の金属表 面技術にも利用できるのではなかららか。Dyer $5^{34)}$ の 研究によれば,アノード分極時に溶解してピット内に濃 縮した $\mathrm{Al}^{3+}$ が，カソード分極時に $\mathrm{Al}(\mathrm{OH})_{3}$ として皮 膜形成にあずかる。これは水素発生に伴なら界面 $\mathrm{pH}$ の 増大によるものである。そして次のアノードサイクル時 に, この皮膜の弱点部が破壊, 溶解するので, サイコロ

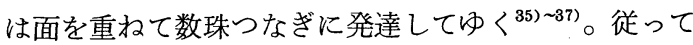
交流の波形, 周波数, 電流密度等の最適な組合せが重要 である ${ }^{36)}$

一方 DC ェッチングでは, (100)面が残り，サイコロ 状にエッチングされるので, 均一溶解には表面に平行に (100)面が揃うような素材調整が必要である。

\subsection{2 熱水処理}

$\mathrm{Al}$ を熱水中に浸せきすると, 擬べーマイトと呼ばれ る水和酸化物皮膜が生成する ${ }^{38)}$ 。この皮膜には耐圧はな い。高橋, 工藤, Bernard ら ${ }^{392}$ 41) によれば, この皮膜 は比較的ち密な内層と, 繊維状の外層とからなる。

熱水処理後の試料を化成すると, 通常の無定型バリヤ 一皮膜のほかに, 水和酸化物皮膜が徐々に脱水, 変質し て複合酸化物皮膜が生ずる。そしてこの皮膜は結晶性と 無定型の両酸化物層から成ることが, 永山, 工藤, 清水 ら ${ }^{39,40), 42) ~ 44)}$ によって明らかにされている。化成中に化 学的な転換によるバリヤー皮膜の生成が加味されるので, 電流効率は $120 \%$ 以上 ${ }^{42)}$ 亿もなるので省電力になり, 高 い電場強度 $(10 \mathrm{~A} / \mathrm{V})$ を保持できるので高容量がえられ る。

しかしながら, 結晶皮膜への転換で体積が縮小するの でボイドが生じ39), 最外層に羽毛状皮膜ができるので $\tan \delta$ が大きくなるという欠点を克服することが必要で ある。また加藤らの研究 (未発表) によれば, 化成後の LC は確かに低いが，これを熱処理した時の LC 低下度 は少なく, 熱水処理をしない皮膜のそれに比べて LC は 高くなる。

\subsection{3 熱酸化処理}

化成前の試料を加熱 $\left(450^{\circ} \mathrm{C}\right.$ 以上)すると非晶質皮膜と 共に微小な結晶性皮膜が生成する ${ }^{45)}$ 。これを化成すると， 前記熱水処理とほぼ同様な現象が起こるとされている。

3.5.4 化成前のリン酸塩処理

加藤らは, 試料を高温のリン酸塩溶液中に浸せき後,
耐水和性に劣る化成液 (Ad, B 液等) 中で化成すると耐 水和性が著しく改善されることを見い出した。化成後の 皮膜内リン分布を調べたところ, 皮膜の極く外層部分 (全厚の $2 \%$ )にのみリン酸イオンの存在を認め, これが 耐水和性向上の原因であることを明らかにした ${ }^{46)}$ 。

\section{4. よ め}

以上の情報から㷌納される結果は, 次のように要約さ れる。

バリヤー皮膜は,「ち密で, 高い絶縁性をもつ皮膜で ある」，というような単純な言葉で定義できるほど簡単 なものではない。その特性は, 試料の前処理, 化成条件, 化成前後の加熱や各種水溶液, 高温水中等への浸せきな ぞの処理に大きく依存し, 結晶性の有無, 結晶化度, 水 和の程度, 介在イオン濃度扣よび混入アニオンの種類, 濃度, 分布等が複雑に変化し, それによって漏兄い電流, 誘電正接, 容量, 絶縁破壊電圧, 耐水和性, 耐酸性, 漏 えい電流の経時変化等の特性が顕著に変化する。

つまり, 皮膜は環境の変化に極めて敏感であり, あた かも環境との間で呼吸をする生物体のような感じを受け る。従ってバリヤー皮膜の特性が，もっと明らかになれ ば，付与する外的条件をコントロールして，所望の特性 をもつ皮膜を設計できるようになるであるう。

(1988-2-24 受理)

\section{文献}

1) M. Kato, T. Goshima, Y. Kaneko and T. Kudo ; Proceeding of INTERFINISH '80, p. 250 (1980)

2）加藤正義；工化誌，68，1636（1965）

3）高橋英明，広瀬 剛，永山政一; 金属表面技術，36，149 (1985)

4) P.G. Anderson and O.F. Devereux ; J. Electrochem. Soc., 122, 267 (1975)

5) A. Libsch and O.F. Devereux ; J. Electrochem. Soc., 122, 1654 (1975)

6) H. Takahashi and M. Nagayama ; Electrochim. Acta, 23, 279 (1978)

7) Y. Sasaki ; J. Phys. Chem. Solids, 29, 249 (1968)

8) C.P. Bean; J.C. Fischer and D.A. Vermilyea ; Phys. Rev., 101, 551 (1956)

9) J.F. Dewald; J. Phys. Chem. Solids, 2, 55 (1957)

10) L. Young ; Proc. Roy. Soc. (London) A263, p.395 (1961)

11）工藤忠人, 加藤正義, 渡瀬真生; 電気化学, 40,792 (1972)

12) M. Kato; Electrochim. Acta, 21, 593 (1976)

13）加藤正義, 工藤忠人；電気化学， 44，738（1976）

14）加藤正義, 工藤忠人; 電気化学, 46, 449 (1978)

15）加藤正義, 福島信人, 横井清弘, 工藤忠人; 金属表面技術, 34, 384 (1983)

16) H.Konno, S. Kobayashi, H. Takahashi and M. Nagayama; Corrosion Science, 22, 913 (1982)

17）川野一忠, 馬場宣良, 田島 栄; 電気化学, 40, 29, 632 (1972)

18) J.E. Lilienfeld ; Trans. Electrochem. Soc., 58, 225 (1930) 
19) S. Ikonopisov ; Electrochim. Acta, 22, 1077 (1977)

20) F.J. Burger and J.C. Wu ; J. Electrochem. Soc., 118, 2039 (1971)

21) J.B. Cotton and A.C. Wood ; Trans. Inst. Chem. Eng., 41, 11 (1963)

22) J. Yahalom; Electrochim. Acta, 15, 877, 1429 (1970)

23）加藤正義，内田悦美，工藤忠人，金属表面技術，35，475 (1984)

24) N. Sato ; Electrochim. Acta, 16, 1683 (1971)

25）犬石嘉雄, 中島達二, 川辺和夫; 誘電体現象論, p.291 (電気学会, 1973）からの間接引用

26) N. Wüthrich ; Electrochim. Acta, 25, 819 (1980) N. Wüthrich ; Electrochim. Acta, 26, 1617 (1981)

27) J.B. Kushner ; Plating, 41, 1146 (1954)

28）瀬尾真治；日本金属学会誌，26，793（1987）

29) F. Forlani and N. Minnaiar ; J. Vac. Sci. Tech., 6, 518 (1969)

30）工藤忠人, 加藤正義, 渡瀬真生 ; 電気化学, 40,792 (1972)

31）加藤正義, 藤井健一郎, 工藤忠人; 電気化学, 43, 746 (1975)

32) H. Konno, S. Kobayashi, H. Takahashi and M. Nagayama ; Electrochim. Acta, 25, 1667 (1980)

33）永山政一; 電気化学, 53，862（1985）
34) C.K. Dyer and R.S. Alwitt ; J. Electrochem. Soc., 128, 300 (1981)

35) H.J. de Wit and H.M. Boots ; J. Appl. Phys., 54, 2727 (1983)

36）松本健三, 立花和宏, 船越 明, 菅沼栄一; 金属表面技術, 38, 246 (1987)

37）丹野裕司, 菅沼栄一; 金属表面技術, 38，341（1987）

38) D. Altenpol and W. Post ; J. Electrochem. Soc., 108, 628 (1961)

39）高橋英明，梅原康敏，宮本 武，藤本紀文，永山政一，金 属表面技術，38，67（1987）

40) T. Kudo and R.S. Alwitt ; Electrochim. Acta, 23, 341 (1978)

41) W.J. Bernard and JJ. Randall ; J. Electrochem. Soc., 107 , 483 (1960)

42）高橋英明，梅原康敏，永山政一，金属表面技術，38，138 (1987)

43) C. Crevecoeur and H.J. de Wit ; Extended Abstract, p.132, 27th I.S.E. Meeting (Zurich, 1976)

44）小林賢三, 清水健一，藤原 晃；軽金属，35，611（1985）

45）R.S. Alwitt（工藤忠人訳）；金属表面技術， 32， 226 (1981)

46）加藤正義, 福島信人，堀井弘子，工藤忠人，金属表面技術 協会第67回講演大会講演要旨集, p.88（1983） 